\title{
A distributed and co-operative environment to help the rehabilitation of children with Down's syndrome
}

\author{
Ana Margarida P. Almeida and Fernando M. S. Ramos \\ Department of Communication and Art, University of Aveiro, Portugal
}

Abstract: This article describes the conceptualisation, prototyping and testing of a distributed learning environment (ANCORA) that allows geographically distributed individuals to share a synchronous visual environment designed under the principles of situated learning and shared construction of knowledge.

Beyond some brief details on the characterisation of the target audience, the paper presents the ANCORA conceptual model and its theoretical foundations, and describes the approach used in the prototyping process. Moreover, it describes the evaluation and trial strategy and, finally, some ideas concerning future work.

Key words: rehabilitation, co-operative work, web-based learning, situated learning, open evaluation

\section{INTRODUCTION AND OBJECTIVES}

Rehabilitation, namely of children with Down's syndrome, is usually associated with 'closed and shamed' institutions, poorly connected with the daily lives of most other citizens. With this work we hope to create new learning opportunities for those children (whose learning standards do not follow the most common development profiles) through the development of an internet-based open environment providing a rich learning environment, situated and adapted to the user's specific needs.

A special concern is the study of the role of distributed environments in the socialisation and integration processes of children with special needs. In this sense, we intended to underline the importance of the contexts in the learning and rehabilitation processes and, also, to exploit the social dimension of rehabilitation. We therefore considered a shared and situated 
space as a social interface platform of mediation and communication, underlining the importance of a constant interaction between individuals and contexts: indeed, deficiency is far beyond a phenomenon of mental or motor dysfunction, and can be characterised as a dynamic multi-dimensional phenomenon that includes educational, behavioural and social aspects (WHO, 1999).

\section{USERS' NEEDS AND SPECIFICITIES}

As we deeply believe that it is highly important to diagnose and study the target audience before implementing an on-line learning environment (Redmond-Pyle and Moore, 1995) a main requirement of this research was the adoption of a learning environment model well adjusted to the specificities of children carrying Down's syndrome.

Down's syndrome is the most frequent genetic cause of mental retardation, affecting up to 1 in 700 live births. Recent investigations into the DNA sequence of this chromosome found that it represents around 1-1.5\% of the human genome (Reeves, 2000). Considering cognitive disorders, individuals with Down's syndrome present some linguistic handicaps resulting from hearing difficulties and from other problems concerning simultaneous and sequential cognitive processes, namely chronological understanding, successive event synthesis, sequential hearing memory and recently acquired knowledge construction (Condeço et al., 1999). Although these limited language skills can be responsible for the intensification of already present difficulties in symbolic and social areas, Sigman states that, when compared with other mentally retarded groups, children with Down's syndrome are socially communicative and capable of imaginary play (Sigman and Rusjin, 1999).

Also, children carrying Down's syndrome like to learn by themselves through experience and do not appreciate close adult mediation, benefiting from distal communication processes (mediated by tools and artefacts which children may point and manipulate freely) instead of from the common proximal ones (human related and without many mediation objects) (Condeço et al., 1999). This evidence strengthened the idea of designing a technologically mediated communication platform to help Down's syndrome children to work collaboratively on a team basis, simultaneously offering a distal approach and minimising face-to-face contacts. 


\section{FOUNDATIONS AND CONCEPTUAL MODEL}

The ANCORA conceptual model is deeply rooted in the specificities and needs of its target audience. The core concept is the deployment of a collaborative learning environment able to integrate the individual learning profiles through a global and shared dynamic, promoting the transference of knowledge acquired into a full social integration.

The conceptual model adopted also exploits the potentialities of the utilisation of story discourses as structuring platforms of contexts and as frameworks for learning, enabling rehabilitation of a deficit in a chronological understanding typical of Down's syndrome. According to Schank (1998), story construction favours contextualisation, generalisation and consolidation of knowledge, but also participation and integration processes.

It is, also, our belief that learning phenomena are situated processes because human cognition and learning are embedded in specific contexts and are constituted through processes of interdependence, socially and ecologically grounded and mediated by tools and artefacts (Litteton and Häkkinen, 1999). This approach is in line with Clancey's (1997) situated cognition theories, which state that cognitive processes are contextually situated. The model is, then, based on interactive role-playing schemes allowing children to participate in the activities through the manipulation of characters, scenarios and objects and the consequent shared construction of learning environments. Figure 1 depicts the model used in ANCORA. The different individuals (children and therapist) share a collaborative environment, presented as a graphical scenario.

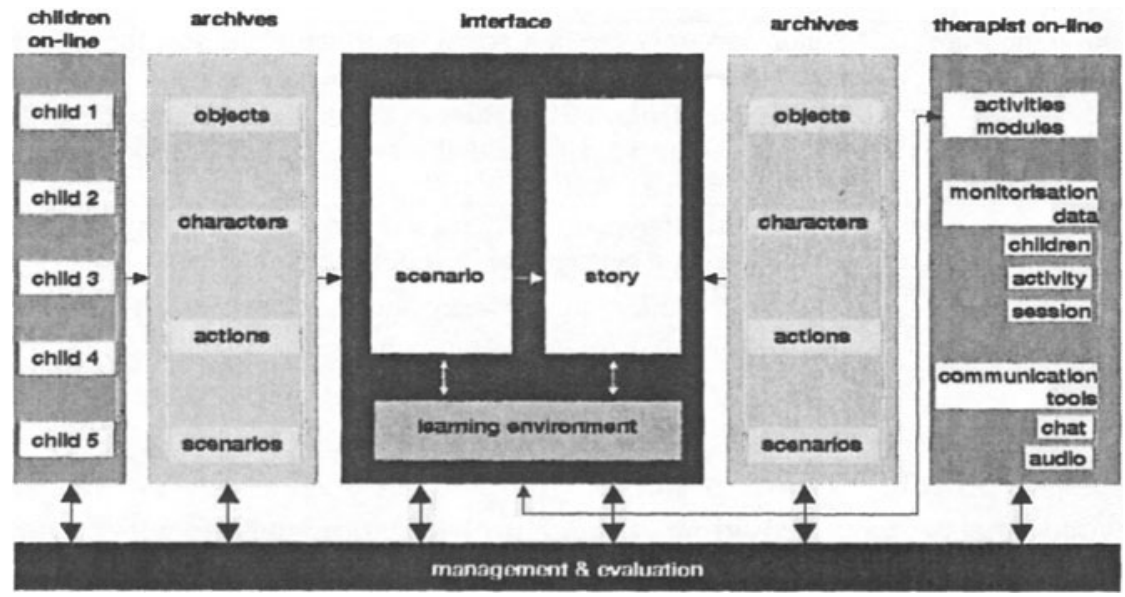

Figure 1. Conceptual model used in ANCORA 
To interact and participate, children move characters, objects and actions that they can manipulate to build a scenario that creates a story. The on-line therapist mediates communications and launches activities, which take place above the multi-modular and shared environments built by the children, favouring processes of situated learning and natural knowledge. Besides this, there is a management layer that enables the collection and display of management information.

\section{PROTOTYPE}

In order to enable the test and validation of the conceptual model, briefly described above, a prototype was implemented. The prototype deploys a TCP/IP distributed networked environment that allows the access of geographically dispersed users.

\begin{tabular}{|l|l|}
\hline $\begin{array}{l}\text { Support to the } \\
\text { user's interaction }\end{array}$ & $\begin{array}{l}\text { Simple and intuitive graphical interfaces enabling the direct } \\
\text { manipulation of objects. }\end{array}$ \\
\hline $\begin{array}{l}\text { Users' } \\
\text { management }\end{array}$ & Login and password validation and registration of new users. \\
\hline $\begin{array}{l}\text { Collaboration } \\
\text { among users }\end{array}$ & $\begin{array}{l}\text { Collaboration using the networked distributed environment, } \\
\text { independently of the users' geographical location. }\end{array}$ \\
\hline $\begin{array}{l}\text { Communications } \\
\text { control }\end{array}$ & $\begin{array}{l}\text { Transfer of information among the users and between each user } \\
\text { and the server. }\end{array}$ \\
\hline $\begin{array}{l}\text { Database } \\
\text { management }\end{array}$ & $\begin{array}{l}\text { Database access, including the users' registration data base and all } \\
\text { the multimedia elements used as building blocks in the scenarios } \\
\text { and activities. }\end{array}$ \\
\hline $\begin{array}{l}\text { White-board } \\
\text { sharing/scenarios' } \\
\text { creation }\end{array}$ & $\begin{array}{l}\text { Scenarios shared construction through direct manipulation (drag } \\
\text { and drop) of the entities previously stored in the databases. }\end{array}$ \\
\hline $\begin{array}{l}\text { Automatic story } \\
\text { building }\end{array}$ & $\begin{array}{l}\text { Automatic story creation according to the entities of the scenario } \\
\text { and to the temporal order in which they were placed. }\end{array}$ \\
\hline $\begin{array}{l}\text { Activities } \\
\text { launching }\end{array}$ & $\begin{array}{l}\text { Invocation of situated activities of rehabilitation depending on the } \\
\text { entities of the scenario and the story created by the group of } \\
\text { children on-line. }\end{array}$ \\
\hline $\begin{array}{l}\text { Voice } \\
\text { communication }\end{array}$ & $\begin{array}{l}\text { Voice transmission, in real time, enabling synchronous } \\
\text { communication between the therapist and the children on-line. }\end{array}$ \\
\hline Text chat & $\begin{array}{l}\text { Text communication between the on-line therapist and the } \\
\text { companion (adult) of the on-line child. }\end{array}$ \\
\hline
\end{tabular}

Table 1. Prototype functionalities

The architecture of the prototype is based on a client-server approach. Beyond the server, providing the central location where all common resources are located, four different client types were defined: child (an interface which presents the minimum complexity and that takes maximum advantage from display space for scenarios and activities), therapist (an 
interface which assures the monitoring and supervision of all the activities carried out by the children and includes functions concerning recording and processing of all data), parent (functionalities for retrieval of general information concerning the environment), and administrator (tools for system management, including user data-base management, communication management and fault recovery).

Following the conceptual approach, summarised above, the prototype supports a comprehensive set of functionalities, briefly identified in Table 1 .

\section{EVALUATION}

For the evaluation of the effectiveness of the model adopted, a descriptive and open evaluation was performed, aimed at understanding the phenomena in all their complexity and in a natural context, through a methodological process that identifies the understanding of the behaviours from the perspective of the subjects in the research (Bodgan and Bilken, 1994).

The tests were conducted with two groups of five children from two institutions working with Down's syndrome: APPT21 (the Portuguese Association of Down's Syndrome) and Capuchinho (a psychological support centre).

\subsection{Formative evaluation}

As a wide and multi-disciplinary evaluation, the ANCORA evaluation was structured in two basic stages: a first stage of formative evaluation and a second stage, of more width, of global evaluation.

The formative evaluation aimed at carrying out feedback during the development of the prototype, helping to find the most adequate solutions for the target audience: during the prototype implementation, and in order to verify the system and conformity of the interface in terms of the adopted usability and accessibility norms, a heuristic evaluation of the interface was also conducted, based on Nielsen usability heuristics (Nielsen) and on an inspection of the conformity of the interface with a checklist based on the W3C guidelines for web content accessibility (see web-site).

Beyond these procedures, different simulation and testing sessions were also conducted in order to verify prototype robustness. 


\subsubsection{Diagnosis and characterisation of the test groups}

Aiming at a full characterisation of the set of children that compose the groups for evaluation of ANCORA, different tests were undertaken. Besides a socio-economic characterisation of the children's families, a diagnosis of computational abilities was carried out. This diagnosis was done in two main stages: an initial characterisation of the computational experience of the children, and a phase of tests on levels of interaction with the input devices.

The initial characterisation of the computational experience showed that the majority of the children from APPT 21 had better results concerning previous experience, familiarisation with diverse devices, diversity of contexts of use, types of applications and success rates. Globally, between the mouse and the keyboard, the mouse was the device most used and preferred by the majority of the children.

The tests concerning interaction with the input devices were conducted with the mouse, track-ball, touch-screen and keyboard. The results of these tests showed that the touch-screen was the device with best results $(80 \%$ without aid), followed by the mouse ( $48 \%$ without aid). Considering the evolution of the sessions, we concluded that the majority of the children showed good capacity to progress their learning about how to work with the different input devices, the mouse showing the best results.

Although the touch-screen was revealed as the most effective solution because it offered the best results, we consider the mouse as the most appropriate solution because it provides good results at a very low cost, enabling the possibility for affordable and realistic solutions for as many organisations as possible.

\subsection{Final evaluation}

The global evaluation was structured in ten different sessions with the participation of the two groups of five children (Scerbo, 1995), an on-line therapist and with an adult helping each child to interact with the system.

The collection of data was performed both through automatic data collection (such as the task's execution time and the level of success of the activities) and through participant observation and video recording.

Prior to the test session, the relevant parameters to observe were systematised and a register grid was prepared (Pereira, 1995), enabling the experience to be documented through controlled and rigorous conditions. Independent, and previously trained, observers were in place to record results for every relevant item for future analysis. The grid used covered the documentation of behaviour concerned with nine main items: tasks, motivation, distraction, use of input devices, system errors, stopping being 
on-task, interruptions, voice communications, and text communications. There is also a final open field in which the observer registers additional remarks.

Final interviews were also conducted with children and with the companion adults.

\section{CONCLUSIONS AND FUTURE WORK}

The work carried out in this research project showed that current information and communication technologies, including the internet, could provide a good basis to deploy effective solutions to help the rehabilitation of children with Down's syndrome, especially useful for children with no easy access to specialised care. Furthermore, this project also showed that technological mediation is appropriate to and easily integrated by children with Down's syndrome, and that it leads to real progress in the development of their cognitive competences.

This work also confirms the importance of the multidisciplinary approach in the development of solutions for people with special needs, engaging in a process of mutual influence between the specificities of the target audience, the formal conceptualisation of the model, the integration of the available technological solutions, and an appropriate design of the graphical interfaces.

The next steps include the setting up of an internet-based community of people interested in the development of distributed and internet-based solutions to help the rehabilitation of people with Down's syndrome, which will be a forum to share information about developments and the application of ANCORA.

Because many of the paradigms used in ANCORA may be generalised, the intention is to study how they may be applied to other communities of people with special needs, in order to help spread the benefits of the 'Information Society' to those communities who are often marginalised.

\section{REFERENCES}

Bodgan, R. and Bilken, S. (1994) Investigação Qualitativa em Educação, uma introdução à teoria e aos métodos. Porto: Porto Editora

Checklist of Checkpoints for Web Content Accessibility Guidelines 1.0. Available at: http://www.w3.org/TR/WCAG10/full-checklist.html

Clancey, W.J. (1997) Situated Cognition: On Human Knowledge and Computer Representations. Cambridge: Cambridge University Press 
Condeço, T., Cotrim, L., Palha, M. and Buckley, S. (1999) Ensino da leitura para o desenvolvimento da linguagem. Revista Integrar $n^{\circ}$. 17, Setembro/Janeiro 1999, Secretariado Nacional para a Reabilitação das Pessoas com Deficiência

ICIDH-2, International Classification of Functioning and Disability, Beta-2 Draft, Short Version (1999). Geneve: World Health Organisation, Assessment, Classification and Epidemiology Group

Litteton, K. and Häkkinen, P. (1999) Learning Together: Understanding the Processes of Computer-Based Collaborative Learning. In P. Dillenbourg (ed.) Collaborative Learning, Cognitive and Computational Approaches. Oxford: Pergamon, Elsevier Science

Nielsen, J. How to conduct a heurist evaluation. Available at: http://www.useit.com/papers/heuristic/heuristic_evaluation.html

Pereira, L.M. (1995) Serviços Multimédia para Pessoas com Deficiência ou Idosas. Faculdade de Motricidade Humana, Universidade Técnica de Lisboa, Lisboa.

Redmond-Pyle, D. and Moore, A. (1995) Graphical User Interface Design and Evaluation, a practical process. Upper Saddle River, New Jersey: Prentice Hall

Reeves, R.H. (2000) Recounting a Genetic Story. Nature magazine, Vol. 405, 18 May 2000

Scerbo, M. (1995) Usability Testing. In J. Weimer (ed.) Research Techniques in Human Engineering. Upper Saddle River, New Jersey: Prentice Hall

Schank, R.C. (1998) Tell me a Story, Narrative and Intelligence. Illinois: Northwestern University Press

Sigman, M. and Rusjin, E. (1999) Continuity and Change in the Social Competence of Children with Autism, Down syndrome and Development Delays. Monographs of the Society for Research in Child Development, Oxford.

\section{BIOGRAPHIES}

Ana Margarida Almeida has a degree in new technologies of communication from the University of Aveiro, Portugal. She is a Ph.D. student of sciences and technologies of communications in the Department of Communication and Art, University of Aveiro, Portugal. Fernando Ramos is head of the Department of Communication and Art at the University of Aveiro, Portugal, and director of the Multimedia and Distance Learning Centre of the same university. His current research activity is focused on management of distributed digital communities.

\section{ACKNOWLEDGEMENTS}

The authors would like to acknowledge and highlight the support received from the Calouste Gulbenkian Foundation which provided financial support for the field trials. A very special thanks also to the staff of the organisations collaborating with this project, the Portuguese Association for Down's Syndrome (APPT21) and Capuchinho, and to the devoted team (Ricardo Marques, Ricardo Gonçalves and Álvaro Sousa) that helped design and engineer the prototype. 